\title{
Life history and assessment of grapevine phylloxera leaf galling incidence on Vitis species in Uruguay
}

\author{
María Valeria Vidart ${ }^{1}$, María Valentina Mujica ${ }^{1}$, Leticia Bao ${ }^{1}$, Felicia Duarte$^{1}$, Carlos María Bentancourt ${ }^{1}$, \\ Jorge Franco ${ }^{2}$ and Iris Beatriz Scatoni ${ }^{1^{*}}$
}

\begin{abstract}
Grapevine phylloxera, Daktulosphaira vitifoliae (Fitch) (Hemiptera: Phylloxeridae) is a worldwide pest of Vitis species. It has forms that feed on leaves and roots. Root forms predominate on Vitis vinifera (L.) cultivars, while leaf forms predominate on Vitis species from its native American range. Recently, high densities of $D$. vitifoliae infestations in leaves of $V$. vinifera in Brazil, Peru, and Uruguay have been reported. The aims of this study were to determine the seasonal development of grape phylloxera, quantify infestation levels on $V$. vinifera leaves, and compare them with infestation levels on leaves of a rootstock of American origin. Studies were conducted in two vineyards in Uruguay from 2004-2007. Terminal shoots of 3309 C and Cabernet Sauvignon, Chardonnay, Tannat, Viognier, grafted onto resistant rootstock, were sampled weekly and leaves examined for gall presence and insect life stage. First galls were detected in early October; eggs began to appear within two weeks. Two oviposition peaks occurred by the end of December, and they coincided with bursts of shoot growth. On 3309C rootstock, oviposition peaks were more frequent than on the European cultivars. Based on thermal accumulation, D. vitifoliae could complete eight generations a year in Uruguay. Rootstock 3309C suffered the greatest damage but in some cases was similar to the European cultivars. Damage to Chardonnay, Cabernet Sauvignon and Viognier were also high. There were no galls on Tannat. The 2005-2006 season was characterized by low infestation rates caused by a prolonged drought that affected vegetative growth. There were also differences between vineyards, where the vigorous plants suffering more damage. Leaf galling phylloxera incidence and damage were mainly associated to the cultivar but plant vigor and environmental factors also contributed to increase the incidence.
\end{abstract}

Keywords: Daktulosphaira vitifoliae, Hemiptera: Phylloxeridae, Seasonal development, Foliage infestation

\section{Introduction}

Grapevine phylloxera, Daktulosphaira vitifoliae (Fitch) (Hemiptera: Phylloxeridae), is an insect pest of Vitis species. It has forms that feed on leaves (gallicolae) and roots (radicicolae). On Vitis species native to North America, $D$. vitifoliae induces galls on leaves and feeds on roots without evident injury. The real impact of grape phylloxera occurred when it was accidentally introduced in Europe and the root forms devastated European grapevine Vitis vinifera L., first in France, then across the continent and eventually the world (Grannet et al. 2001).

\footnotetext{
* Correspondence: iscatoni@fagro.edu.uy

${ }^{1}$ Department of Plant Protection, Faculty of Agronomy, University of the Republic, Ave. E. Garzón 780, Montevideo 12900, Uruguay

Full list of author information is available at the end of the article
}

Consequently, intense interest in this insect emerged. Most modern rootstocks used to control this pest were identified as a result of 19th century research. The resistance of these rootstocks has been extraordinarily persistent, so interest in the bio-ecology of the insect and its damage declined over time. New research has been conducted only intermittently, each time a new viticulture area was colonized or a widely-used rootstock has failed to control D. vitifoliae (Grannet et al. 2001).

The first vines planted in Uruguay were imported by Spanish colonists in the late 18th century; however commercial viticulture has its origins between 1860 and 1870 when two commercially important vineyards were established, one in the north and one in the south of the country. Grape phylloxera was detected on these vineyards

\section{它}

(c) 2013 Vidart et al.; licensee Springer. This is an Open Access article distributed under the terms of the Creative Commons Attribution License (http://creativecommons.org/licenses/by/2.0), which permits unrestricted use, distribution, and reproduction in any medium, provided the original work is properly cited. 
Table 1 Characteristics of the vineyards located at Progreso and Juanicó, Uruguay

\begin{tabular}{llc}
\hline Location & Cultivar & Year planted \\
\hline \multirow{3}{*}{ Progreso } & Cabernet Sauvignon & 1996 \\
& Chardonnay & 1999 \\
& Tannat & 1999 \\
& Viognier & 1999 \\
\hline \multirow{2}{*}{ Juanicó } & Cabernet Sauvignon & 1994 \\
& Chardonnay & 1986 \\
& Tannat & 1994 \\
& Viognier & 1992 \\
& 3309 C & Dateless \\
\hline
\end{tabular}

20 years later, and as in Europe, Uruguayan viticulture was restored through the use of resistant rootstocks, a practice that persists today (Echeverría 2005).

Currently, Uruguay has a vineyard area of approximately 8,000 hectares (DIEA-MGAP 2011) planted mostly with high-quality stock that has been selected and sanitized, thanks to a Vineyard Recovery Plan between 1997 and 2003 (Macagno 2006). Recently, new plantations have suffered $D$. vitifoliae infestations on $V$. vinifera leaves in very high densities and at various locations. Similar situations have been observed in Italy, France, the United States (New York), Peru (Grannet et al. 2001), Brazil (Botton and Walker 2009), Hungary (Molnár et al. 2009) and Austria (Könnecke et al. 2011).

This increased occurrence worldwide of leaf-galling grape phylloxera on $V$. vinifera leaves was unexpected and could have several causes including emergence of new endemic biotypes, breakdown in resistance of novel selected cultivars, or accidental introduction of exotic biotypes on planting material (Grannet et al. 2001).

Uruguayan vineyards are characterized by the lack of insects or mites with systematic effects (Bentancourt and Scatoni 2010). The use of insecticides to manage this crop is an exception, so any pest species that exceeds damage thresholds and requires control measures will alter the population balance of beneficial organisms.

Briozzo and Carbonell (1980) and Scatoni et al. (1981) studied the biology of grape phylloxera in the laboratory and field in Uruguay. These investigations have been recently resumed because of the resurgence of severe phylloxera infestation in the foliage of some $V$. vinifera. The aims of this study were to determine the seasonal development of $D$. vitifoliae to foliage

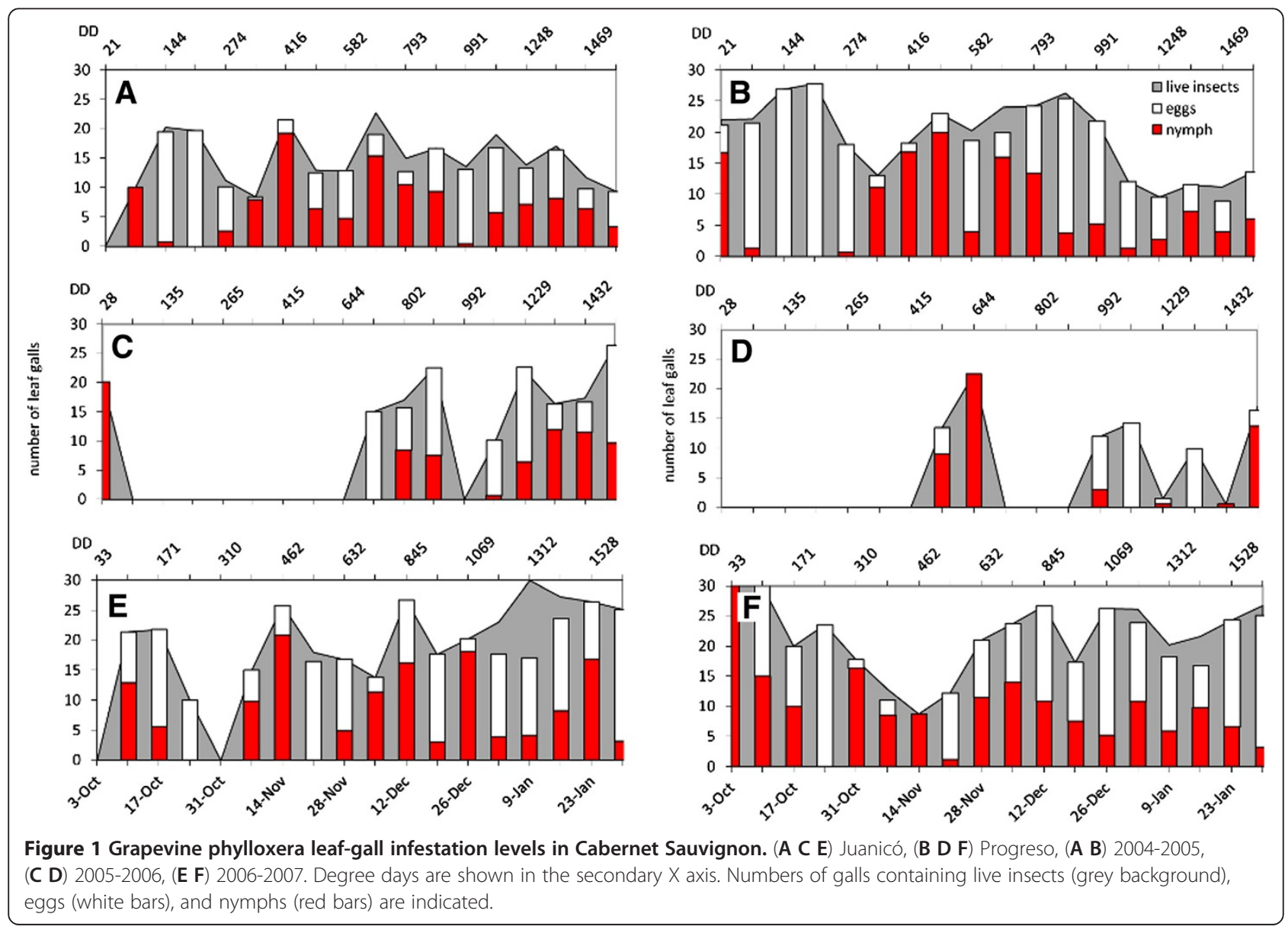


infestation, examine the sensitivity of new $V$. vinifera clones to the leaf-galling grape phylloxera and compare them with infestation levels to leaves of a rootstock of American origin.

\section{Materials and methods}

The study was carried out in two commercial vineyards, $10 \mathrm{~km}$ apart, in Canelones Department, Uruguay, over three consecutive years (2004-2007). One site was located in Juanicó $\left(34^{\circ} 58^{\prime} \mathrm{S}, 56^{\circ} 25^{\prime} \mathrm{W} ; 200\right.$ hectares) and the other in Progreso (34.68' S, 56 $21^{\prime} \mathrm{W}$; 50 hectares). The vineyard located in Juanicó was planted on soil with over 150 years of grapevine history, with average organic matter content of $1.9 \%$, while the vineyard in Progreso was installed on uncultivated soil, without previous history of grapevine and organic matter content ranged between 3.6 and $4.6 \%$ depending on the block. In each location, the $V$. vinifera cultivars Cabernet Sauvignon, Viognier, Chardonnay and Tannat, grafted on SO4 rootstock ( $V$. berlandieri $\mathrm{x} V$. riparia), planted in adjacent blocks were evaluated. In Juanicó, assessments were also performed on a block of American rootstock hybrid $3309 \mathrm{C}$ ( V. riparia $\mathrm{x} V$. rupestris). This rootstock and the Chardonnay cultivar in Juanicó were not assessed in the 2006-2007 growing season because they were removed in the winter. The characteristics of the vineyards are presented in Table 1. Insecticides were not applied in either vineyard during the study period, from 2004-2007.

Every week, from October to March, 10 terminal shoots (15 cm long) were randomly sampled with an average of 6-7 unfolded leaves from each cultivar. In the laboratory, the proportion of leaves with phylloxera galls (a measure of damage incidence) and the number of galls per infested leaf (a measure of severity) were recorded. To evaluate grape phylloxera seasonal development, 30 galls per week and cultivar were randomly taken from the shoot samples. These galls were dissected under stereo-microscope and the presence and insect life stages inside were recorded. Some samples had no galls or too few to evaluate developmental stages.

To predict pest population development, degree day (DD) accumulation from October $1^{\text {st }}$ (biofix) was estimated using $6.4^{\circ} \mathrm{C}$ as a lower threshold temperature (LTT) and $303 \mathrm{DD}$ as a thermal constant $(\mathrm{K})$ to complete a generation (Johnson et al. 2010, Sleezer et al. 2011). Degree days were estimated using the Baskerville and Emin (1969) method based on maximum and minimum air temperatures. Daily maximum and minimum temperatures and precipitation were taken from the Experimental Station of the National

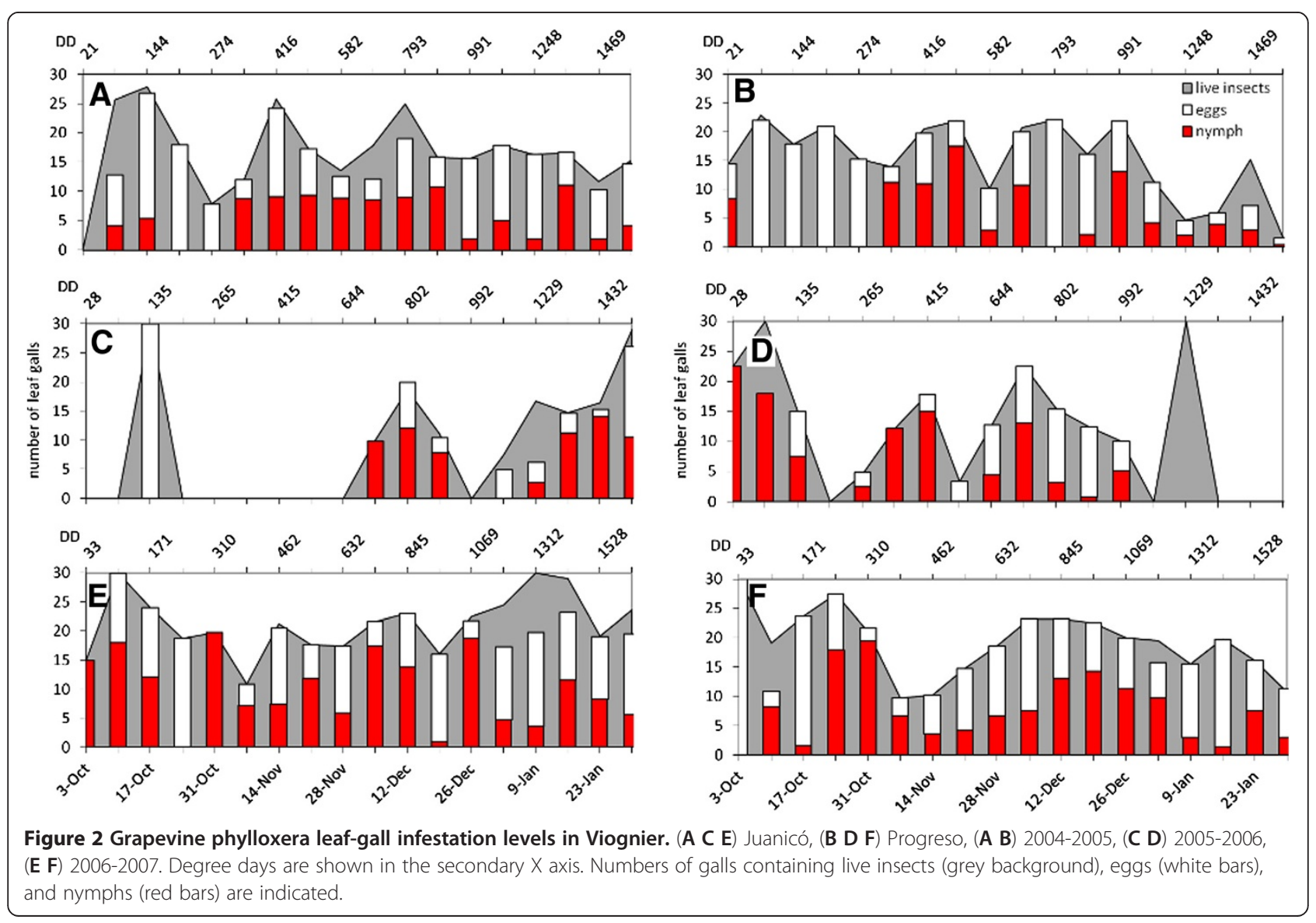


Agricultural Research Institute Las Brujas from 20042007. This station is located 10 and $12 \mathrm{~km}$, respectively, from the Progreso and Juanicó vineyards.

Statistical analyses were done in the framework of generalized linear models (McCullagh and Nelder 1999) assuming a binomial distribution and a logit link function for percentage of leaves with galls and a Poisson distribution with log link function for the number of galls per infested leaf. Finally, to compare incidence and severity of the damage on grape cultivars within each locality in different years, and also to contrast the mean of these variables between locations and years, for cultivars that were present at the two locations in the three years, we applied $\chi 2$ tests. Analyses were done using the GENMOD procedure in SAS v. 9.2 (SAS Institute 2009).

\section{Results and discussion}

\section{Seasonal development of foliage infestation}

Representative graphs are shown for the proportion of leaf galls containing live insects, eggs and four nymphal instars for Cabernet Sauvignon and Viognier in Progreso and Juanicó (Figures 1 and 2, respectively) and 3309 C in Juanicó (Figure 3) for the first two seasons of study, because they were removed after the second season.
In the 2004-2005 and 2006-2007 growing seasons, the first galls with nymphs were found in early October (Figures 1 and 2); these nymphs probably colonized the vegetation up from the roots and rhytidome, considered the main overwintering site. Two weeks later, female oviposition peaked, and eggs began to hatch after approximately 7 days. Through December there were two peaks of oviposition, in general, one in mid-November and the other in December (Figures 1 and 2), coinciding with the greatest abundance of shoots propitious for insect development. This behavior was consistent in both localities and in all European cultivars studied, except Tannat. We found no galls on leaves of Tannat. At least three other generations, which were not clearly defined, could occur from January to March (unpublished data).

On the rootstock $3309 \mathrm{C}$, oviposition peaks were observed more frequently than in the other cultivars (Figure 3); this stock may have a more suitable and abundant food throughout the growing season. $3309 \mathrm{C}$ had the lowest proportion of empty or malformed galls, followed by Cabernet Sauvignon and Viognier. However, several galls were empty in Chardonnay, which would indicate that the insect had difficulty establishing on leaves of this cultivar (unpublished data).
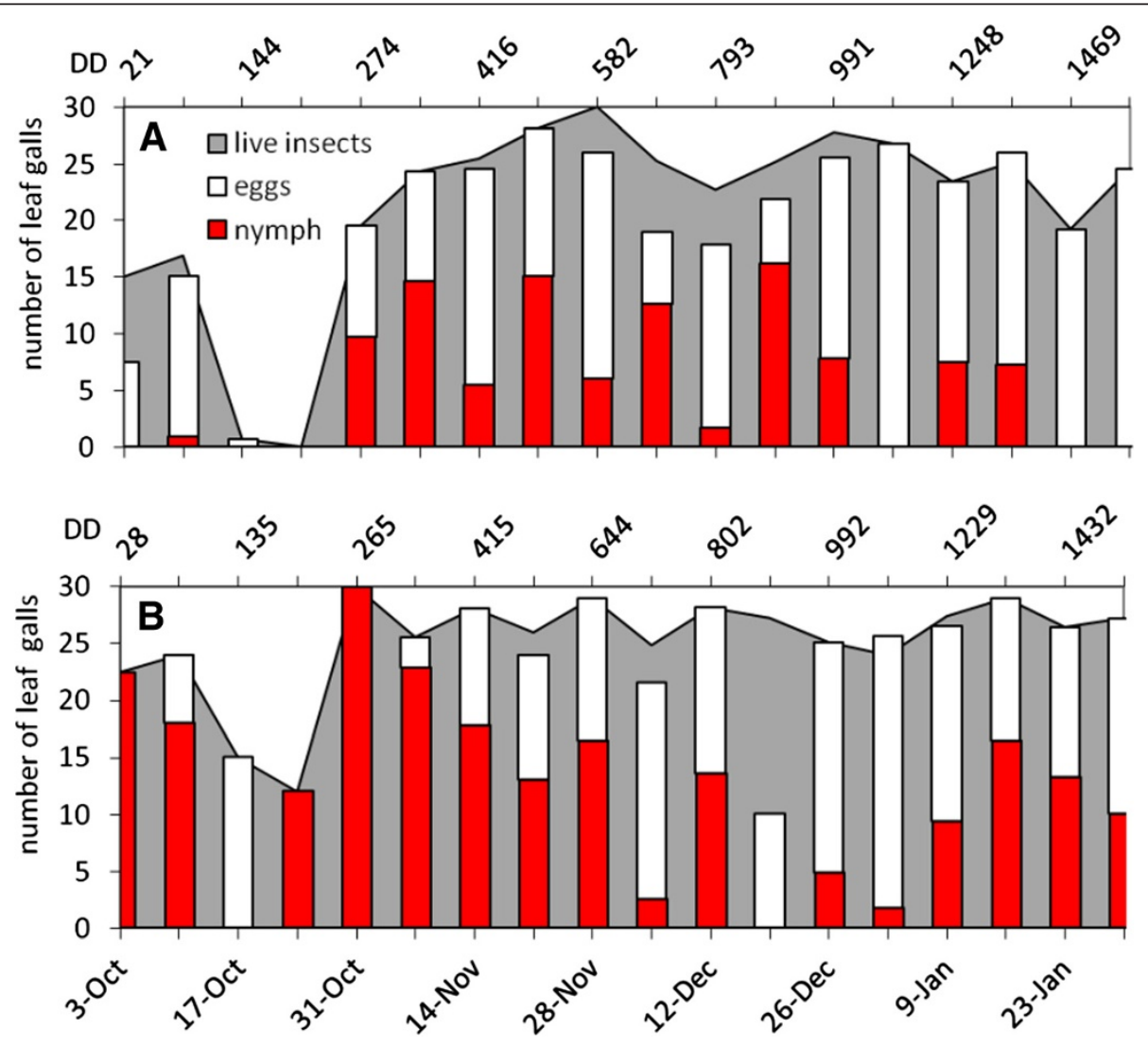

Figure 3 Grapevine phylloxera leaf-gall infestation levels in rootstock 3309 C in Juanicó. (A) 2004-2005, (B) 2005-2006. Degree days are shown in the secondary $X$ axis. Numbers of galls containing live insects (grey background), eggs (white bars), and nymphs (red bars) are indicated. 
Table 2 Predicted start dates of the second and third generations of leaf-form nymphs of Daktulosphaira vitifoliae in Canelones Department, Uruguay

\begin{tabular}{|c|c|c|c|}
\hline Year & Biofix & $\begin{array}{l}\text { Start date } 2^{\text {nd }} \text { generation } \\
\left(\mathrm{K}^{1}=303 \mathrm{DD}, \mathrm{LT}^{2}=6.4^{\circ} \mathrm{C}\right)\end{array}$ & $\begin{array}{l}\text { Start date } 3^{\text {rd }} \text { generation } \\
\left(\mathrm{K}=606 \mathrm{DD}, \mathrm{LTT}=6.4^{\circ} \mathrm{C}\right)\end{array}$ \\
\hline 2004 & $1-$ Oct & 2-Nov & 30-Nov \\
\hline 2005 & 1-Oct & 3-Nov & 26-Nov \\
\hline 2006 & $1-O c t$ & 30-Oct & $25-\mathrm{Nov}$ \\
\hline
\end{tabular}

Note: Dates were estimated from accumulated degree days since October $1^{\text {st }}$ of each year.

${ }^{1}$ Thermal constant and ${ }^{2}$ Lower threshold temperature determined by Johnson et al. 2010.

A different pattern was observed in the 2005-2006 growing season; Cabernet Sauvignon in both localities and Viognier in Juanicó experienced a 1.5-month delay in the first appearance of leaf galls that could not be explained by a lower accumulation of DD (Figures 1 and
2). Accumulated DD in October and November of all three years was very similar, so the predicted beginnings of the second and third generation based on $\mathrm{K}$ were also similar (Table 2). The population fluctuations in each year did not vary substantially among cultivars or between locations.

Development of leaf galling $D$. vitifoliae and associated leaf-galls depends on the quality of substrate and the environmental temperature and humidity (Flaherty et al. 1992). The seasonal development of leaf galling phylloxera under the conditions of this study would seem more strongly affected by the vegetative growth of the vines than with thermal accumulation over the threshold of insect development, although in the 2004-2005 and 2006-2007 seasons development correlated to heat accumulation (Table 2, Figures 1 and 2). Grape phylloxera populations usually increased from bud break until shoot production stabilized in midsummer. Sprouting slows in mid-December which, combined with canopy

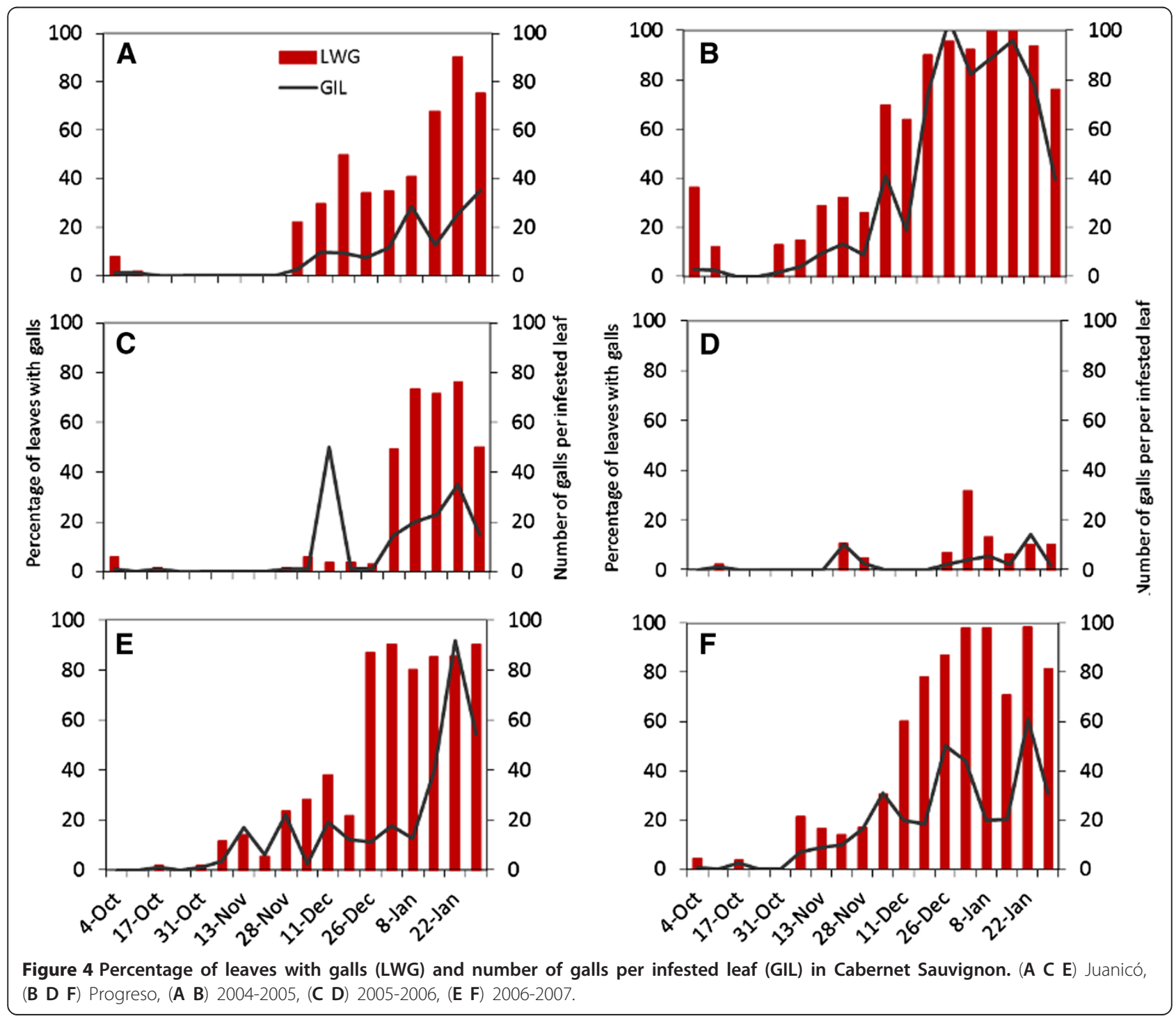


management and green-stage pruning, makes it difficult to locate new leaf galls by removing vegetative tips and lateral shoots in $V$. vinifera cultivars. Although sampling continued into March, those data were not graphed because the galls remaining on the plants were restricted to mature leaves and generally contained only dead insects or remnants of hatched eggs rather than developing insects. On $3309 \mathrm{C}$ where vegetative growth was continuous, insect generations occurred continuously and with substantial overlap of developmental stages (Figure 3). Based on thermal accumulation, D. vitifoliae could complete eight generations a year in Uruguay from October to March, but we could not determine this, due to the large overlap of development stages at the end of the season.

\section{Assessment of damage to foliage}

Figures 4 and 5 show the incidence and severity of grape phylloxera leaf galls on Cabernet Sauvignon and Viognier during the three years of the study. In general, pest incidence was higher in the Progreso vineyard and moderate in Juanicó. Seasonal differences were evident. Clearly, the leaf galling incidence in the 2005-2006 growing season was different from those in other years. In the 2004-2005 season in Progreso, 100\% of leaves from terminal shoots had galls, with an average of 100 galls per leaf, by late December, which did not happen in 2005-2006 on any of the European cultivars. In that season, only the rootstock $3309 \mathrm{C}$ reached $100 \%$ infestation and not until January (Figure 6).

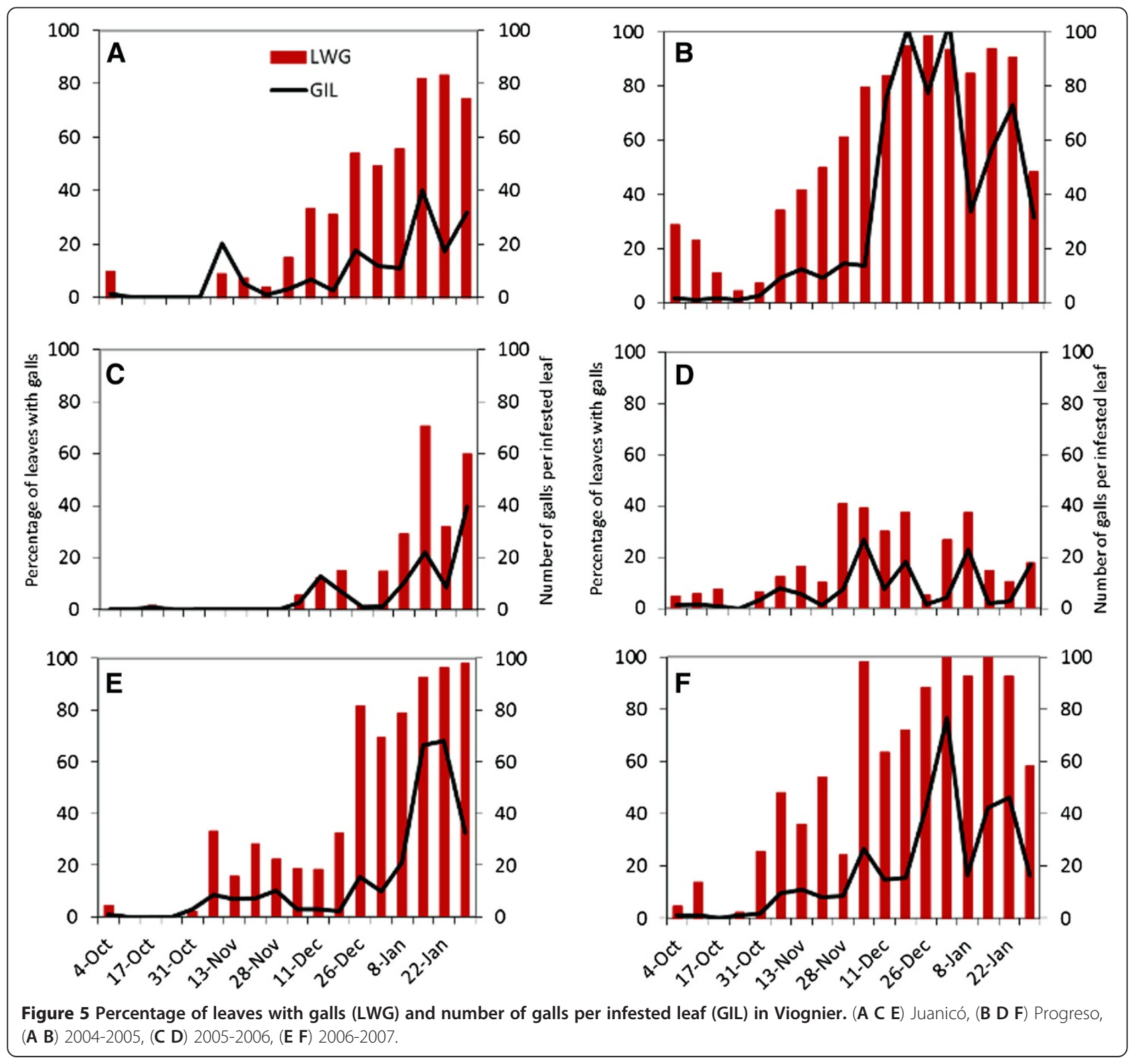




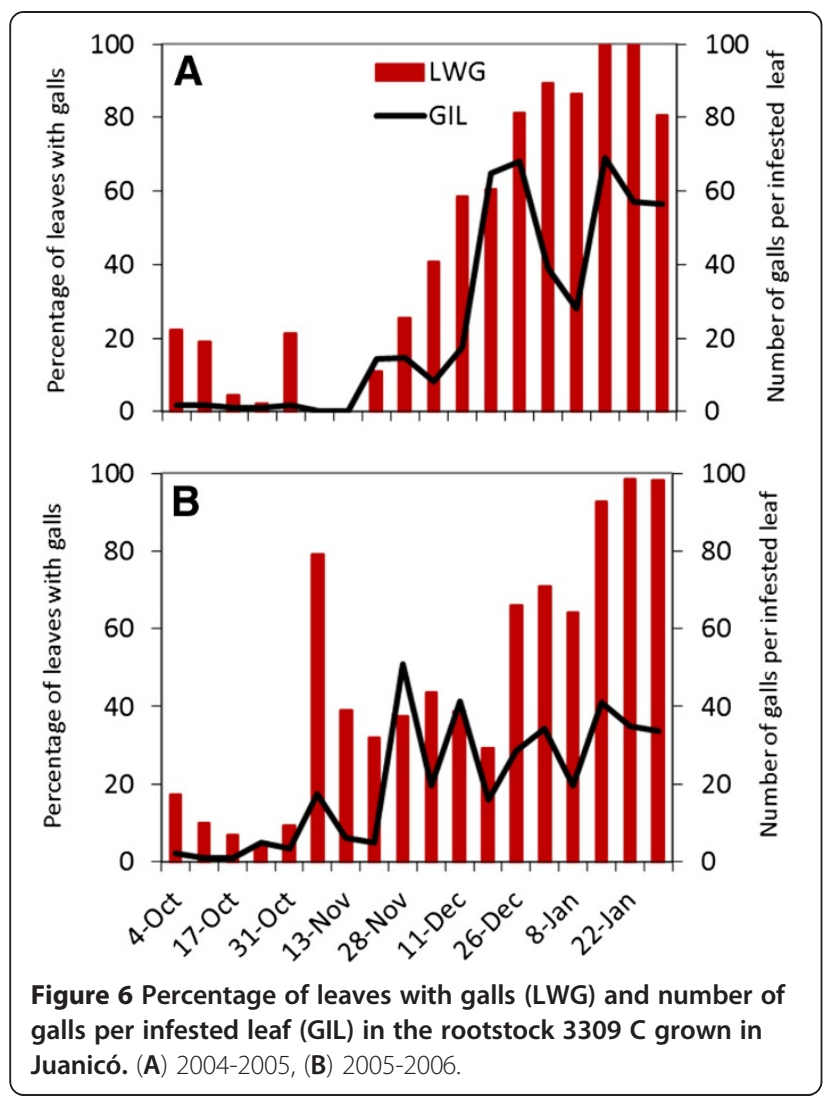

Table 3 summarizes the statistical analyses of the percentage of leaves with galls and the number of galls per infested leaf (October-January), for each cultivar, season, and locality. In Juanicó, rootstock 3309 C showed the highest damage, although in some cases the incidence was similar to that observed in the cultivars Cabernet Sauvignon and Viognier. In this locality, Cabernet Sauvignon and Viognier showed no differences between them comparing the percentage of leaves with galls, but in the 2005-2006 season differed in the severity of damage. Chardonnay was the least attacked cultivar in Juanicó, the lower infestation rates might be explained by their lack of vigor, as they were the oldest vines in this study (Strapazzon and Girolami 1983). Chardonnay, Cabernet Sauvignon and Viognier in Progreso showed similar damage, with narrower differences depending on the season. Tannat was not attacked by $D$. vitifoliae in either of the vineyards in the three years of the study, even when surrounded by infested vineyards, so it was not included in the statistical analysis. Its leaves are probably unfavorable for the insect, but unknown factors could also cause this resistance. The analysis indicated that the average incidence in 2005-2006 was lower in Progreso, but no clear difference among years was evident in Juanicó. However, when comparing only the European cultivars Cabernet Sauvignon and Viognier at both sites and in the three years, on average the 2005-2006 season was different

Table 3 Percentage of leaves with galls (LWG) and galls per infested leaf (GIL), for five grape cultivars, in Juanicó and Progreso, Uruguay

\begin{tabular}{|c|c|c|c|c|c|c|c|c|c|}
\hline \multirow{3}{*}{$\begin{array}{l}\text { Growing } \\
\text { season }\end{array}$} & \multirow{3}{*}{$\begin{array}{l}\text { Cultivar } \\
3309 \text { C }\end{array}$} & \multicolumn{4}{|c|}{ Juanicó } & \multicolumn{4}{|c|}{ Progreso } \\
\hline & & \multicolumn{2}{|c|}{ Mean LWG } & \multicolumn{2}{|c|}{ Mean GIL } & \multicolumn{2}{|c|}{ MeanLWG } & \multicolumn{2}{|c|}{ Mean GIL } \\
\hline & & 58.10 & $a^{*}$ & 45.36 & $a$ & & & & \\
\hline & Chardonnay & 1.20 & c & 4.33 & $d$ & 51.79 & $b$ & 21.39 & d \\
\hline \multirow[t]{5}{*}{ 2004-2005 } & C. Sauvignon & 31.81 & $b$ & 16.16 & $d$ & 67.70 & $a b$ & 70.25 & a \\
\hline & Viognier & 37.05 & $a b$ & 17.80 & $d$ & 70.40 & $a b$ & 55.94 & $\mathrm{~b}$ \\
\hline & Tannat** & 0.00 & & & & 0.00 & & & \\
\hline & $3309 C$ & 55.74 & $a$ & 28.63 & $b$ & & & & \\
\hline & Chardonnay & 2.86 & C & 16.31 & $d$ & 8.80 & $c d$ & 14.36 & e \\
\hline \multirow[t]{5}{*}{$2005-2006$} & C. Sauvignon & 23.00 & $b$ & 23.05 & C & 6.68 & $d$ & 5.79 & e \\
\hline & Viognier & 14.51 & $b c$ & 13.55 & $d$ & 22.09 & C & 12.25 & e \\
\hline & Tannat & 0.00 & & & & 0.00 & & & \\
\hline & $3309 C$ & & & & & & & & \\
\hline & Chardonnay & & & & & 81.18 & $\mathrm{a}$ & 30.18 & C \\
\hline \multirow[t]{3}{*}{ 2006-2007 } & C. Sauvignon & 43.99 & $\mathrm{a}$ & 30.63 & $\mathrm{~b}$ & 54.05 & $\mathrm{~b}$ & 33.08 & C \\
\hline & Viognier & 46.11 & $\mathrm{a}$ & 29.20 & $b$ & 70.72 & $a b$ & 32.12 & C \\
\hline & Tannat & 0.00 & & & & 0.00 & & & \\
\hline
\end{tabular}

* Numbers in a column followed by the same letter are not statistically different $(P>0.05)$ according to the $\chi^{2}$ test when comparing the cultivars in each locality.

** Tannat was not included in the statistical analysis. 
Table 4 Percentage of leaves with galls (LWG) and galls per infested leaf (GIL), for two grape cultivars and three years of study, in Juanicó and Progreso, Uruguay

\begin{tabular}{lllll}
\hline Growing season & \multicolumn{2}{c}{ Mean LWG } & \multicolumn{2}{c}{ Mean GIL } \\
\hline $2004-2005$ & 51.13 & $\mathrm{a}^{*}$ & 47.15 & $\mathrm{a}$ \\
$2005-2006$ & 16.66 & $\mathrm{~b}$ & 15.84 & $\mathrm{~b}$ \\
$2006-2007$ & 53.66 & $\mathrm{a}$ & 31.41 & $\mathrm{a}$ \\
\hline Locality & \multicolumn{2}{c}{ Mean LWG } & \multicolumn{2}{c}{ Mean GIL } \\
\hline Juanicó & 32.10 & $\mathrm{~b}$ & 22.84 & $\mathrm{~b}$ \\
Progreso & 47.59 & $\mathrm{a}$ & 45.76 & $\mathrm{a}$ \\
\hline Cultivar & \multicolumn{2}{c}{ Mean LWG } & \multicolumn{2}{c}{ Mean GIL } \\
\hline Cabernet Sauvignon & 36.79 & $\mathrm{a}$ & 39.37 & $\mathrm{a}$ \\
Viognier & 42.79 & $\mathrm{a}$ & 33.52 & $\mathrm{a}$
\end{tabular}

Note: Comparing the average damage by growing season, locality and cultivar. * Numbers in a column followed by the same letter are not statistically different $(P>0.05)$ according to the $\chi^{2}$ test when comparing the growing seasons, localities and cultivars.

from the others and the incidence and severity of the damage was higher in Progreso, without statistical differences among cultivars (Table 4).

We inferred that the lower incidence of infestation in 2005-2006 might be due to climatic factors acting directly and indirectly on the insect, mainly by affecting the quality of its food. The limited rainfall from August to December 2005 affected vine sprouting and consequently the ability of $D$. vitifoliae to establish galls and reproduce. October is the key month for grape phylloxera establishment, because that is when juveniles ascend

Table 5 Monthly accumulated precipitations $(\mathrm{mm})$ recorded during this study and of a historical series in Canelones Department, Uruguay

\begin{tabular}{lcccc}
\hline Month & \multicolumn{4}{c}{ Precipitation (mm) } \\
\cline { 2 - 5 } & $\mathbf{2 0 0 4 - 2 0 0 5}$ & $\mathbf{2 0 0 5 - 2 0 0 6}$ & $\mathbf{2 0 0 6 - 2 0 0 7}$ & $\mathbf{1 9 6 1 - 1 9 9 0}$ \\
\hline March & 57 & 70 & 163 & 105 \\
April & 212 & 184 & 30 & 86 \\
May & 33 & 93 & 19 & 89 \\
June & 67 & 157 & 245 & 83 \\
July & 51 & 91 & 83 & 86 \\
August & 58 & 46 & 35 & 88 \\
September & 46 & 76 & 41 & 94 \\
October & 156 & 64 & 129 & 109 \\
November & 110 & 38 & 84 & 89 \\
December & 62 & 24 & 112 & 84 \\
January & 199 & 233 & 36 & 87 \\
February & 117 & 50 & 164 & 101 \\
\hline
\end{tabular}

${ }^{1}$ Dirección Nacional de Meteorología, Uruguay, http//www.meteorologia.gub. uy/index.php/estadísticas-climaticas. from the roots to the foliage; in 2005, October was characterized by both low rainfall and above-normal temperatures (Table 5). According to Korosi et al. (2012) high temperatures combined with low relative humidity cause mortality of $D$. vitifoliae dispersive stages in less than two hours.

Leaf galling phylloxera incidence and damage were mainly associated to the cultivar (Table 3 ). The difference between vineyards might be due to plant vigor; overall, the grapevines at the Progreso site were younger (Table 1) and growing in a more fertile soil without previous grapevine history that made the grapevines unevenly balanced with exuberant sprouting. This finding coincides with the observations of Strapazzon and Girolami (1983) for Italy and Molnár et al. (2009) for Hungary, who reported leaf galls on vigorous plants of $V$. vinifera. However, we do not reject the hypothesis that different biotypes exist in both vineyards, which is now being studied (unpublished data).

For gall-forming insects to be successful, they must be present when the target organ is susceptible. Therefore, gall-formers preferably use actively-growing plant tissues (Bauerle et al. 2007). Thus, a more vigorously-growing plant would have more new shoots available to herbivores than a stressed plant (Grannet et al. 2001), which could explain our results. Abundant rains in the spring 2004 and 2006 favored vegetative growth and consequently the leaf galling $D$. vitifoliae incidence in those seasons. Most damage in Progreso was also due to a higher vegetative growth associated with greater soil fertility and younger plants.

Grape phylloxera uses many Vitis species as hosts. The complex interactions among grape cultivar and physiology, environmental conditions, and the phylloxera biotype and its physiology that affect gall formation have a mechanistic basis that has not yet been explained. Because gall formation is a prerequisite for phylloxera survival and growth and the consequent vine damage, understanding these mechanisms has a great practical significance (Grannet et al. 2001).

Our results, observations and experiences confirm the necessity for an in-depth investigation of grape phylloxera leaf galling, especially on the factors that could be leading to the different susceptibility among cultivars of $V$. vinifera. It is clear that environmental factors (climate, soil) and grape phylloxera biotypes may be contributing. However, the cultivar Tannat in both vineyards was growing under the same environmental conditions, came from the same nursery, had the same age, was surrounded by infested cultivars and did not presented leaf galls throughout this study. Tannat is the predominant cultivar in Uruguay, their sources of resistance to leaf galling $D$. vitifoliae should be clarified, and maybe they could be useful in future plant breeding programs. 


\section{Competing interests}

The authors declare that they have no competing interests.

\section{Authors' contributions}

Proposed the topic, conceived and designed the study: IBS CMB JF. Carried out the experimental study (field and laboratory work), collected and tabulated the data for the statistical analysis: MW MVM LB FD. Analyzed the data and helped in their interpretation: JF. Wrote the manuscript and collaborated with the corresponding author in the revised version of the manuscript: IBS MW CMB LB. All authors read and approved the final manuscript.

\section{Acknowledgments}

We thank to the Comisión Sectorial de Investigación Científica (CSIC) of the Universidad de la República and the Instituto Nacional de Vitivinicultura (INAVI) for their financial support of this project. Special thanks go to the Juanicó and Pisano establishments for allowing and helping with this research in their vineyards. We also thank the anonymous reviewers for their invaluable contributions and suggestions to the original manuscript.

\section{Author details}

${ }^{1}$ Department of Plant Protection, Faculty of Agronomy, University of the Republic, Ave. E. Garzón 780, Montevideo 12900, Uruguay. ²Department of Biometry, Statistics and Computation, Faculty of Agronomy, University of the Republic, Ave. E. Garzón 780, Montevideo 12900, Uruguay.

Received: 26 February 2013 Accepted: 16 April 2013

Published: 23 April 2013

\section{References}

Baskerville GL, Emin P (1969) Rapid estimation of heat accumulation from maximum and minimum temperatures. Ecology 50:515-517

Bauerle TL, Eissenstat DM, Granett J, Gardner DM, Smart DR (2007) Consequences of insect herbivory on grape fine root systems with different growth rates. Plant Cell Environ 30:786-795

Bentancourt C, Scatoni I (2010) Guía de insectos y ácaros de importancia agrícola y forestal en el Uruguay. Hemisferio Sur, Montevideo, 589p

Botton M, Walker MA (2009) Grape Phylloxera in Brazil. Acta Hort 816:39-40

Briozzo J, Carbonell J (1980) Desarrollo de las infestaciones de "Filoxera" Phylloxera vitifoliae (Fitch) (Homoptera: Phylloxeridae) en follaje de vid. Investigaciones Agronómicas 1:9-11

DIEA-MGAP (2011) Anuario Estadístico Agropecuario. Ministerio de Ganadería Agricultura y Pesca, Montevideo, 246p

Echeverría G (2005) La viticultura en el Uruguay. Facultad de Agronomía, Montevideo, 80p

Flaherty DL, Christensen LP, Lanini WT, Marois JJ, Phillips PA, Wilson LT (1992) Grape pest management. Div. Agric. Natl. Res., Univ. Calif, Oakland, p 400p

Grannet J, Walker MA, Kocsis L, Omer AD (2001) Biology and management of grape phylloxera. Annu Rev Entomol 26:387-412

Johnson DT, Sleezer S, Lewis B (2010) Biology and management of grape phylloxera. Univ. Arkansas Cooperative Extension Service Fact Sheet FSA7074., www.uaex.edu/Other_Areas/publications/PDF/FSA-7074.pdf. Accessed 22 May 2010

Könnecke T, Aigner C, Specht S, Lawo NC, Forneck A (2011) A stepwise assessment of Daktulosphaira vitifoliae infested grapevines in a Viennese vineyard site. Acta Hort 904:59-62

Korosi GA, Mee PT, Powell KS (2012) Influence of temperature and humidity on mortality of grapevine phylloxera Daktulosphaira vitifoliae clonal lineages: a scientific validation of a disinfestation procedure for viticultural machinery. Aust J Grape Wine Res 18:43-47

Macagno LF (2006) Reconversion and development program of the farm; final project report (online). IDB, Montevideo, p 30, Available in http://idbdocs. iadb.org/wsdocs/getdocument.aspx?docnum=837262. Accessed 14 December 2012

McCullagh P, Nelder JA (1999) Generalized linear models. Chapman and Hall, London, $511 \mathrm{p}$

Molnár JG, Németh CS, Májer J, Jahnke GG (2009) Assessment of phylloxera leaf galling incidence on European grapevines in Badacsony Hungary. Acta Hort 816:97-104

SAS Institute (2009) SAS/STAT 9.2 User's Guide. SAS Publishing, Cary, North Carolina, p 584
Scatoni I, Chiaravalle W, Muzante J (1981) Filoxera de la vid, Viteus vitifoliae (Fitch) (Homoptera: Phylloxeridae) en el Uruguay. Tesis, Facultad de Agronomía, Montevideo, p 48

Sleezer S, Johnson DT, Lewis B, Goggin F, Rothrock C, Savin M (2011) Foliar Grape Phylloxera, Daktulosphaira vitifoliae (Fitch), Seasonal Biology, Predictive Model and Management in the Ozarks Region of the United States. Acta Horticulturae 904:151-156

Strapazzon A, Girolami V (1983) Foliar phylloxera infestations (Viteus vitifoliae (Fitch)) with completion dell'olociclo on Vitis vinifera (L.) engaged. Redia 66:179-194

\section{doi:10.1186/2193-1801-2-181}

Cite this article as: Vidart et al:: Life history and assessment of grapevine phylloxera leaf galling incidence on Vitis species in Uruguay. SpringerPlus 2013 2:181.

\section{Submit your manuscript to a SpringerOpen ${ }^{\circ}$ journal and benefit from:}

- Convenient online submission

- Rigorous peer review

- Immediate publication on acceptance

- Open access: articles freely available online

- High visibility within the field

- Retaining the copyright to your article

Submit your next manuscript at $>$ springeropen.com 